\title{
GEOGRAPHICAL ANALYSIS OF SOCIAL AMENITIES AND SERVICES IN THE KASHMIR VALLEY OF THE HIMALAYAN REGION
}

\author{
Altaf Hussain \\ Former Student of Department of Regional Planning, \\ School of Planning and Architecture, New Delhi. \\ DOI: 10.46609/IJSSER.2020.v05i06.011 URL: https://doi.org/10.46609/IJSSER.2020.v05i06.011
}

\begin{abstract}
Social amenities and services are the representation of the social, cultural and economic development. The development is supposed to be inclusive in term of social amenities and services like electricity, health centres, toilets, drinking water, schools, housing, communication and so on. These infrastructures are essential and integral part of human life of any community living in rural and urban areas. This study is about the availability and accessibility of social infrastructure in the Kashmir valley. It has been found from this study that Kupwara, Ganderbal, Bandipora and Kulgam districts are least developed in terms of social amenities and services There has been given less emphasis to the socio-economic development of these districts compared to other districts. These districts are still deprived from the availability and accessibility of social amenities and services in the Kashmir valley. The poor policies and lack of good governance have been led to the unequal and unplanned distribution of social infrastructure in this region.
\end{abstract}

Keywords: Kashmir Valley, Social Amenities, Services, Districts, Region

\section{INTRODUCTION}

Amenity is defined as "a location-specific good and encompasses all aspects of the consumption or production decision that influence the location of the household or firm" (Diamond \& Tolley, 1982, pp. 5-6). Social Amenities are considered as a crucial determinant of people's well-being. Accessibility to basic amenities is significant to well-being and a suitable standard of living (Kumar, 2015). Social infrastructure has significant role in the process of growth and capacity building by increasing quality of human livelihood with education, healthcare and recreation facilities. There is a gap of demand and supply of infrastructure and social amenities, which have been led to poor sanitation, lack of drinking water, sewerage problems and lack of services. 


\section{International Journal of Social science and Economic Research}

ISSN: $2455-8834$

Volume: 05, Issue: 06 "June 2020"

There is supposed to be reduced the gap between demand and supply by taking considerations of future implications (Haque I. , 2016).

Development and human livelihood is predominantly determined by basic needs such as food, clothing, water and shelter. These needs and other requiremnts can be fulfilled when people have proper access to facilities like housing, water supply, electricty, market and transportation (Aderamo \& Aina, 2011).The investments into the cities and districts required adequate social infrastructure support in the form of transportation, education, housing, basic amenities and services (Bagchi \& Chattopadhyay, 2004). Although, the access to basic amenities is also determined quality of urbanisation (Bhagat, 2011).

The United Nations are given emphasis towards achieving Millennium Development Goals (MDGs) encompassing employment opportunities, social protection, basic requirements, services access for all inclusively. This can be achieved by strengthening governance and revamping the international policy and harnessing the power of all stakeholders judiciously. Moreover, there should be left behind no person anywhere in this age of technological advancement. There is not supposed to live hungry, without shelter, without clean water and sanitation, without access to basic health services and education. These basic amenities are human rights of people in order to live have a decent life (United Nations General Assembly, 2013).

There has been mentioned in the state development report (SDR) of Jammu and Kashmir that the actual challenge of development lies in reducing the gap between poor and rich through povertyreduction programmes. The SDR is emphasized on the well-being of people, widening of their opportunities, measuring deprivation, highlighting the shortcomings of the development, identification of new resources and partnerships for practical solution. There have been suggested a policy framework for revamping the development process that addresses intra-state disparities and diversities (Planning Commission, 2003). For instance; Integrated Child Development Service (ICDS) scheme is implemented by the central government to provide employment, reduce poverty and improve the quality of life in the Kashmir valley. This scheme has also ensured basic infrastructure and assets essential for development of the region (Haque \& Wani, 2013).

The state governments and institutions are not shown interests in favour of small and medium towns of Indian states in terms of investment and infrastuctural development (Kundu, Bagchi, \& Kundu, 1999). They suggested that the restructuring of municipilaties and governance system can bring drastic changes in accessibilty and basic amenities of people. To have balanced regional development has always been India's national development strategy in order to ensure the unity and integrity of the nation (Mohiuddin \& Hashia, 2012). They have been argued that regional differences are occurred due to variations in physical and natural endowments, 
differences in social thinking, behavioural thinking, institutional structures and by the discriminatory policies of the state towards its people.

\section{STUDY AREA}

Kashmir valley lies between the Karakoram and the Pir Panjal range in the Indian state of Jammu and Kashmir. It is also one of the administrative and natural regions of the Jammu and Kashmir state. The valley is encircled by mountain ranges characterized by snow covered high mountain peaks and has an area of 15,984 square kilometres. The total population of Kashmir valley is 6.908 million which is almost half the total population of 12.55 million of Jammu and Kashmir state (Census of India, 2011). Jhelum and its tributaries like Lidder, Indus, Bring, Vishav, Pohru, Sandran, and Surkhnag are prominent rivers of the Valley. The Kashmir valley consists of the following districts: Budgam, Bandipore, Anantnag, Baramulla, Ganderbal, Kulgam, Pulwama, Kupwara, Shopian and Srinagar. It lies between the coordinates of $73^{\circ} 55^{\prime} \mathrm{E}$ and $75^{\circ} 35^{\prime} \mathrm{E}$, and $35^{\circ} 25^{\prime} \mathrm{N}$ and $34^{\circ} 45^{\prime} \mathrm{N}$.

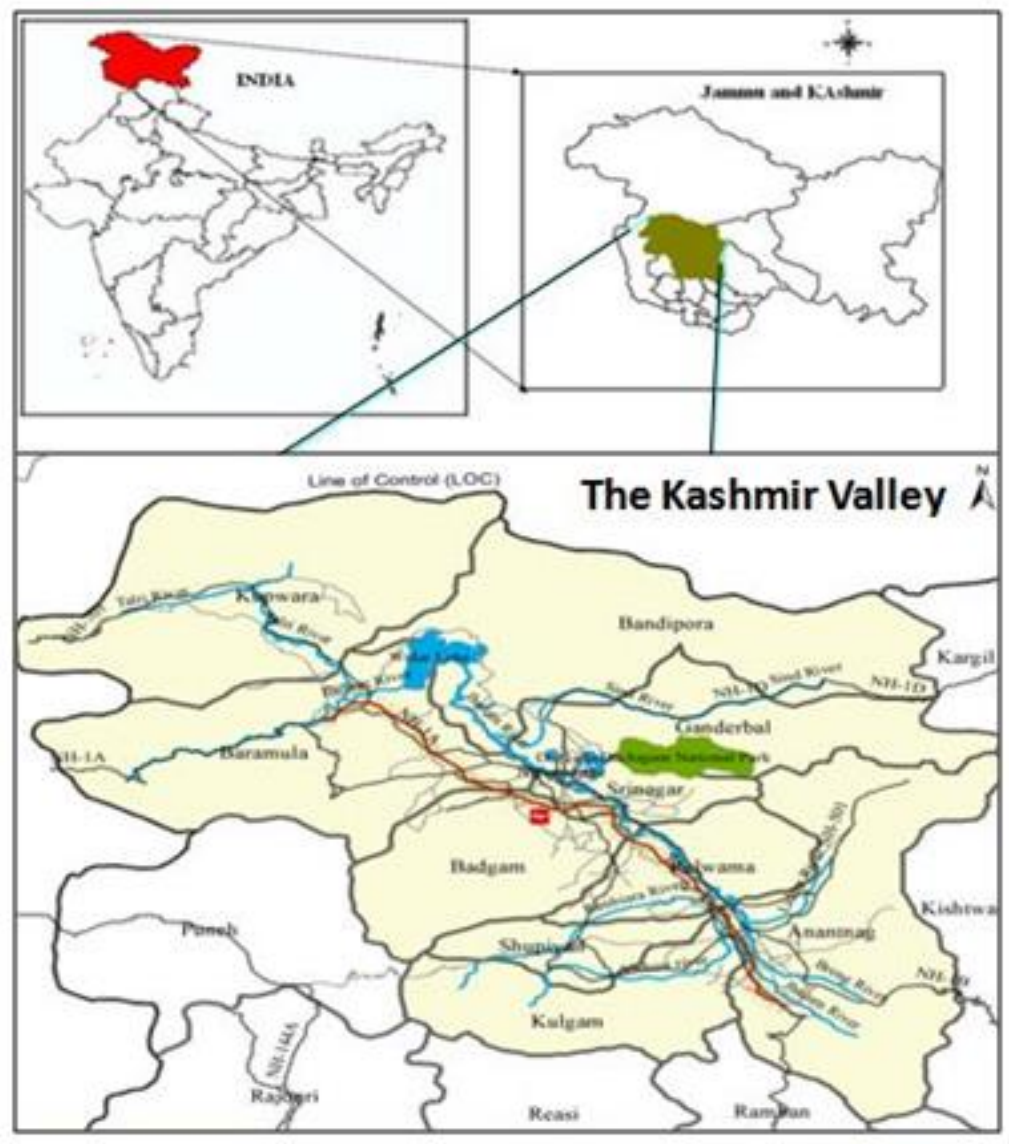

Source: OpenStreetMap,2016(https://www.openstreetmap.org/) 


\section{OBJECTIVE}

To study and analyze the availability and accessibility of social amenities and services in the Kashmir valley.

\section{DATABASE AND METHODOLOGY}

The aim of this study is to assess the existing conditions of social amenities and services in the Kashmir valley. The literature review has been done with the help of journals, articles, books and other sources. Secondary sources are the main database for this study. The data have been extracted from the census of India (primary census abstract) and from the census report of the directorate of economic and statistics department of Jammu and Kashmir. On the basis of selected indicators from the secondary sources, there has been tried to find out the existing conditions of the social amenities and services in terms of electricity, drinking water, housing, hospital, schools, toilets and other social services. The selected indicators are calculated at districts level statistically. After that, there has been done comparison of each indicators with the Kashmir valley average as well as the state average. The software tools like QGIS and ArcMap have been used for the purpose of analysing and preparing maps for the study of the Kashmir valley. The indictors which have been chosen for this study is given below in the table 1 .

Table 1: Indicators of the Social Amenities and Services (2011-12)

\begin{tabular}{|c|c|c|c|c|c|c|c|}
\hline $\begin{array}{c}\text { Seri } \\
\text { al } \\
\text { No. }\end{array}$ & $\begin{array}{c}\text { District } \\
\text { name }\end{array}$ & $\begin{array}{l}\text { Household } \\
\text { s with } \\
\text { electricity } \\
\text { (in \%) }\end{array}$ & $\begin{array}{c}\text { Households } \\
\text { with treated } \\
\text { drinking } \\
\text { water (in \%) }\end{array}$ & $\begin{array}{c}\text { Households } \\
\text { with using } \\
\text { firewood (in } \\
\%)\end{array}$ & $\begin{array}{c}\text { Households } \\
\text { with using } \\
\text { LPG/NPG } \\
\text { (in \%) }\end{array}$ & $\begin{array}{l}\text { Households } \\
\text { with latrine } \\
\text { (in \%) }\end{array}$ & $\begin{array}{c}\text { No. of } \\
\text { school } \\
\text { per } 100 \\
\text { sq.km }\end{array}$ \\
\hline 1 & Kupwara & 78 & 13 & 80 & 15 & 51 & 121 \\
\hline 2 & Badgam & 91 & 30 & 56 & 15 & 84 & 125 \\
\hline 3 & Baramula & 95 & 37 & 64 & 23 & 78 & 165 \\
\hline 4 & Bandipora & 80 & 17 & 67 & 16 & 74 & 123 \\
\hline 5 & Srinagar & 99 & 82 & 6 & 82 & 98 & 708 \\
\hline 6 & Ganderbal & 89 & 55 & 69 & 24 & 73 & 66 \\
\hline 7 & Pulwama & 91 & 30 & 61 & 21 & 66 & 134 \\
\hline 8 & Shupiyan & 84 & 25 & 70 & 9 & 61 & 102 \\
\hline 9 & Anantnag & 80 & 24 & 72 & 20 & 57 & 62 \\
\hline 10 & Kulgam & 69 & 8 & 76 & 6 & 45 & 105 \\
\hline $\begin{array}{c}\text { Seri } \\
\text { al } \\
\text { No. }\end{array}$ & $\begin{array}{c}\text { District } \\
\text { name }\end{array}$ & $\begin{array}{c}\text { No. of } \\
\text { medical } \\
\text { institution } \\
\text { per } 100 \text { sq. } \\
\text { km }\end{array}$ & $\begin{array}{c}\text { Occupied } \\
\text { census } \\
\text { houses used } \\
\text { as } \\
\text { hospital/disp } \\
\text { ensary etc. }\end{array}$ & $\begin{array}{c}\text { Occupied } \\
\text { census } \\
\text { houses used } \\
\text { as } \\
\text { shop/office } \\
\text { (in \%) }\end{array}$ & $\begin{array}{c}\text { Occupied } \\
\text { census } \\
\text { houses used } \\
\text { as school/ } \\
\text { colleges etc. } \\
\text { (in \%) }\end{array}$ & $\begin{array}{c}\text { Occupied } \\
\text { census } \\
\text { houses used } \\
\text { as } \\
\text { hotel/lodge/ } \\
\text { guest house }\end{array}$ & $\begin{array}{c}\text { Road } \\
\text { length } \\
\text { per } 100 \\
\text { sq.km }\end{array}$ \\
\hline
\end{tabular}


International Journal of Social science and Economic Research

ISSN: $2455-8834$

Volume: 05, Issue: 06 "June 2020"

\begin{tabular}{|c|c|c|c|c|c|c|c|}
\hline & & & (in \%) & & & etc. (in \%) & \\
\hline 11 & Kupwara & 20 & 0.26 & 9.49 & 1.23 & 0.09 & 56 \\
\hline 12 & Badgam & 16 & 0.18 & 9.46 & 0.88 & 0.08 & 133 \\
\hline 13 & Baramula & 28 & 0.21 & 10.86 & 1.15 & 0.16 & 112 \\
\hline 14 & Bandipora & 9 & 0.15 & 8.43 & 0.94 & 0.09 & 89 \\
\hline 15 & Srinagar & 121 & 0.15 & 17.62 & 0.57 & 0.56 & 968 \\
\hline 16 & Ganderbal & 16 & 0.22 & 9.97 & 0.84 & 0.16 & 43 \\
\hline 17 & Pulwama & 14 & 0.15 & 9.6 & 0.7 & 0.07 & 124 \\
\hline 18 & Shupiyan & 15 & 0.14 & 10.52 & 0.84 & 0.07 & 122 \\
\hline 19 & Anantnag & 19 & 0.14 & 10.5 & 0.69 & 0.26 & 85 \\
\hline 20 & Kulgam & 12 & 0.15 & 8.91 & 0.73 & 0.04 & 76 \\
\hline
\end{tabular}

\begin{tabular}{|c|c|c|c|c|c|c|c|}
\hline $\begin{array}{c}\text { Seri } \\
\text { al } \\
\text { No. }\end{array}$ & $\begin{array}{c}\text { District } \\
\text { name }\end{array}$ & $\begin{array}{c}\text { No. of } \\
\text { registered } \\
\text { vehicles } \\
\text { per } 100 \\
\text { sq.km }\end{array}$ & $\begin{array}{l}\text { No. of post } \\
\text { offices per } \\
100 \text { sq.km }\end{array}$ & $\begin{array}{c}\text { Households } \\
\text { with } \\
\text { availability } \\
\text { of television } \\
\text { (in } \%)\end{array}$ & $\begin{array}{c}\text { Households } \\
\text { with } \\
\text { availability } \\
\text { of mobile (in } \\
\% \text { ) }\end{array}$ & $\begin{array}{c}\text { Households } \\
\text { with } \\
\text { availability } \\
\text { of car/ } \\
\text { jeep/van (in } \\
\% \text { ) }\end{array}$ & $\begin{array}{c}\text { Househol } \\
\text { ds with } \\
\text { availabili } \\
\text { ty of } \\
\text { computer } \\
\text { /laptop } \\
\text { (in \%) }\end{array}$ \\
\hline 21 & Kupwara & 331 & 3 & 25 & 50 & 2 & 4 \\
\hline 22 & Badgam & 1996 & 6 & 54 & 66 & 5 & 6 \\
\hline 23 & Baramula & 1034 & 18 & 51 & 66 & 6 & 76 \\
\hline 24 & Bandipora & 574 & 8 & 45 & 55 & 3 & 5 \\
\hline 25 & Srinagar & 6453 & 49 & 91 & 72 & 20 & 20 \\
\hline 26 & Ganderbal & 29 & 2 & 47 & 56 & 5 & 6 \\
\hline 27 & Pulwama & 786 & 7 & 56 & 70 & 8 & 7 \\
\hline 28 & Shupiyan & 1024 & 2 & 47 & 71 & 9 & 8 \\
\hline 29 & Anantnag & 1231 & 15 & 47 & 63 & 6 & 6 \\
\hline 30 & Kulgam & 762 & 10 & 37 & 67 & 3 & 5 \\
\hline
\end{tabular}

Source: Directorate of Economic and Statistical Department, (DESD), Jammu \& Kashmir, 2011-12 and Census of India, Primary Census Abstract, 2011

\section{RESULTS AND DISCUSSION}

The unprecedented increasing population and urbanisation have been affecting the livelihood of people in terms of drinking water, toilets, housing, transport, solid wastes and other services particularly in urban centres of the districts. Social and physical infrastructures have always been in critical conditions because of the rapid increasing of population and urbanisation. Although, militancy and topographical disadvantage have also led to the low level of development in the Kashmir valley. There has been discussed each aspect of social amenities and services in the following paragraphs with their results. 


\section{Map 1: No. of Medical Institutions per 100 sq. km and Percentage Share of Occupied Census Houses used as Hospital/Dispensary etc. (2011-12)}

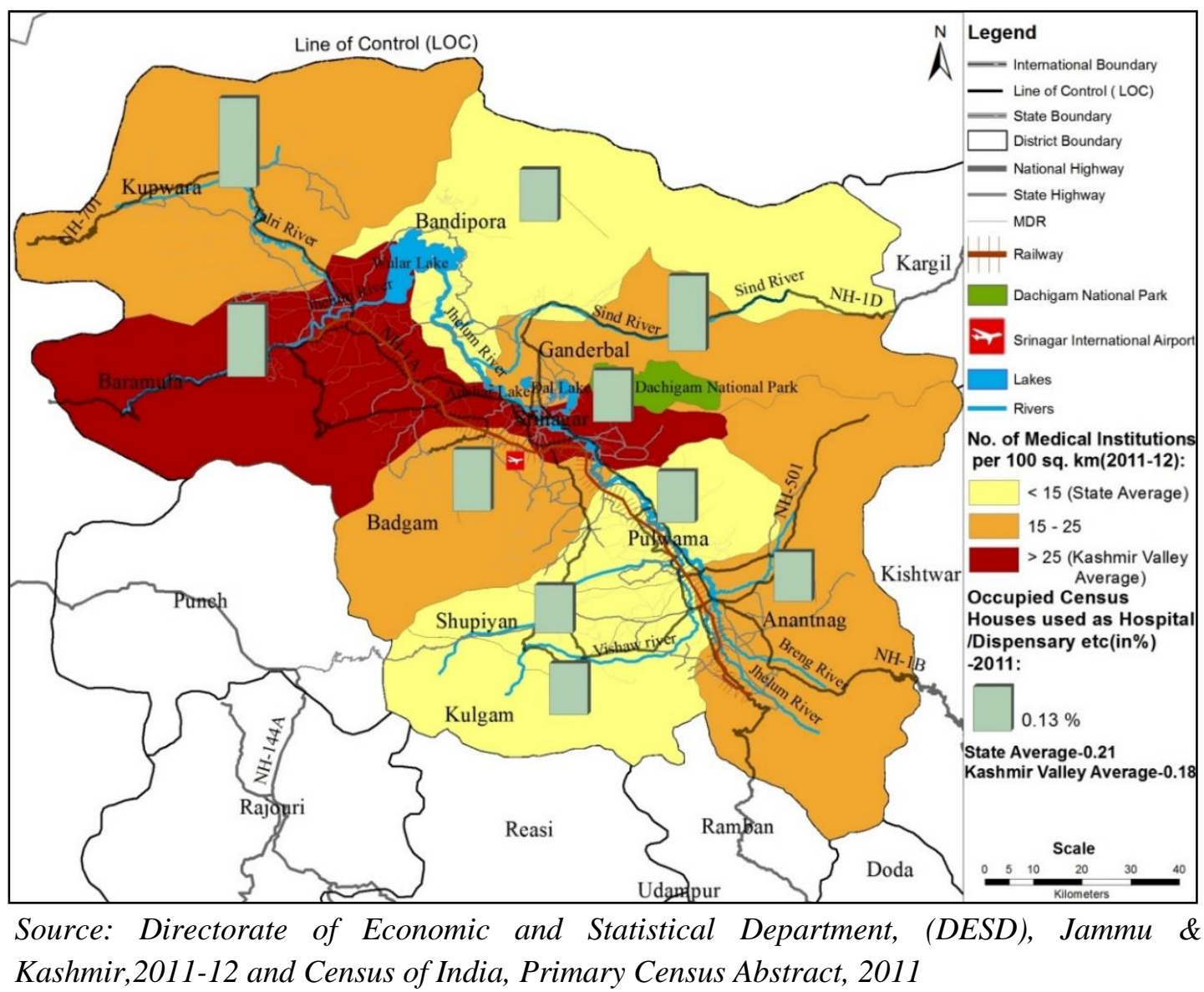

Healthcare have always been a major issue in this region. Medical institutions such as dispensary, hospitals etc are parameters of healthcare system. Number of medical institutions per 100 square $\mathrm{km}$ is lower than the state (15) and Kashmir valley average (25) in the districts of Bandipora, Kulgam, Shupiyan and Pulwama. There is needed to develop medical institutions in these districts. Similarly, it is higher than the Kashmir valley average (25) in Srinagar and Baramulla districts. Percentage share of occupied census houses which are used as hospital/dispensary etc are higher than the state $(0.21 \%)$ and Kashmir valley average $(0.18 \%)$ in the districts of Kupwara, Ganderbal and Baramulla. But in case of Shupiyan and Bandipora, there are fewer occupied census houses which are used as hospital/dispensary etc. 


\section{Map 2: No. of Schools per $100 \mathrm{sq} . \mathrm{km}$ and Percentage Share of Occupied}

Census Houses used as School/College etc. (2011-12)

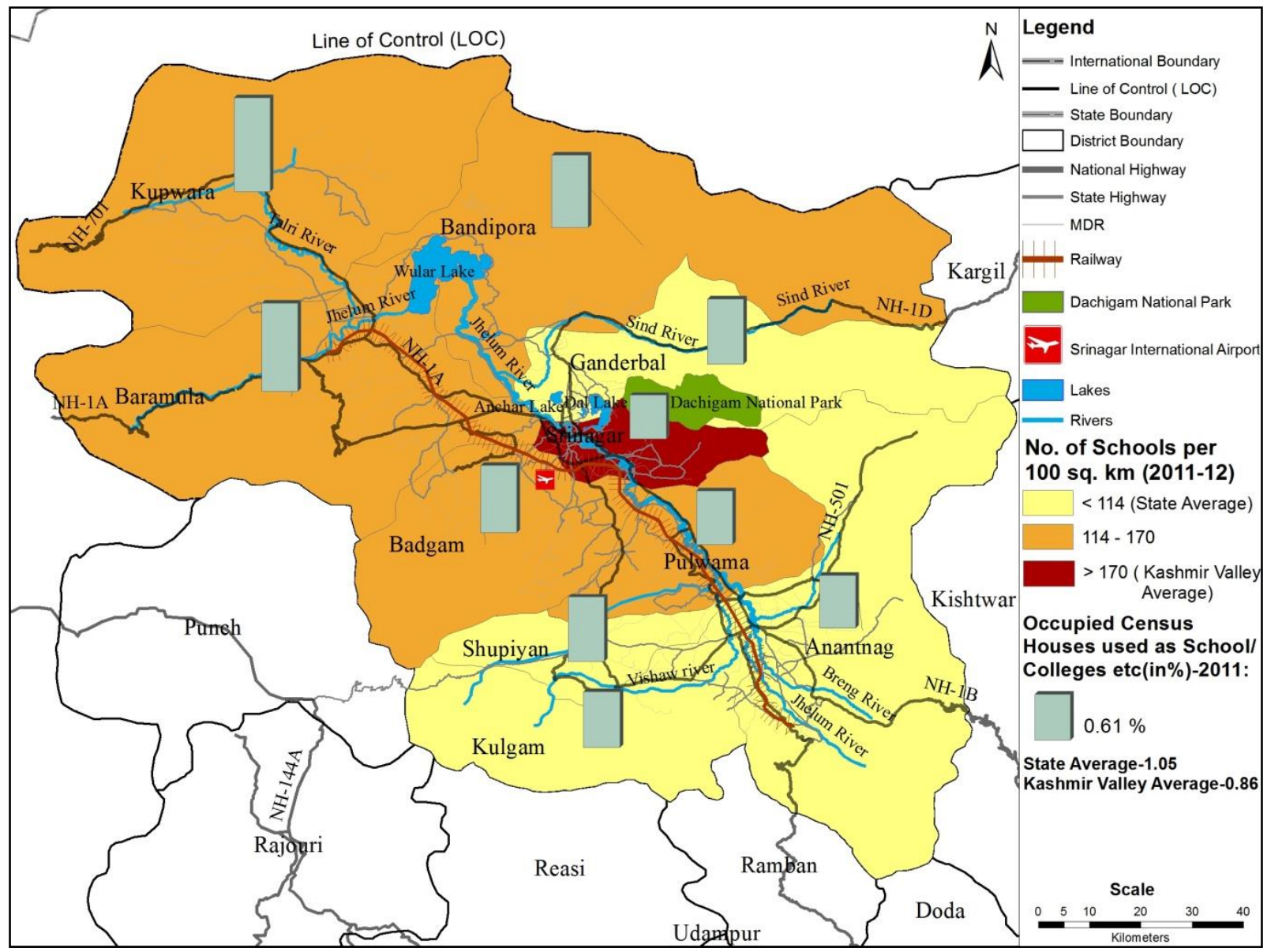

Source: Directorate of Economic and Statistical Department (DESD), Jammu \& Kashmir, 2011-12 and Census of India, Primary Census Abstract, 2011

Educational assets are determining factor of the quality and educational facilities of schools. It has always been challenging to access education because of insurgency and lack of educational infrastructure in the primary and secondary schools notably in the border districts of Kashmir valley. It can be inferred from this map that the educational assets are better in the cities and towns compared to its remote areas. Numbers of schools per $100 \mathrm{sq}$. km are higher than the Kashmir valley average (170) in Srinagar district, while there have been fewer number of schools in Ganderbal, Kulgam, Shupiyan and Anantnag. The percentage share of occupied census houses which are used as school/colleges etc is higher than the state $(1.05 \%)$ and Kashmir valley average $(0.86 \%)$ in Kupwara and Baramula districts. There are fewer occupied census houses used as school/colleges etc in Srinagar (0.57\%), Anantnag (0.69\%) and Pulwama $(0.70 \%)$. 


\section{Map 3: Percentage Share of Households with Latrine and Percentage Share of Households with Treated Drinking Water (2011)}

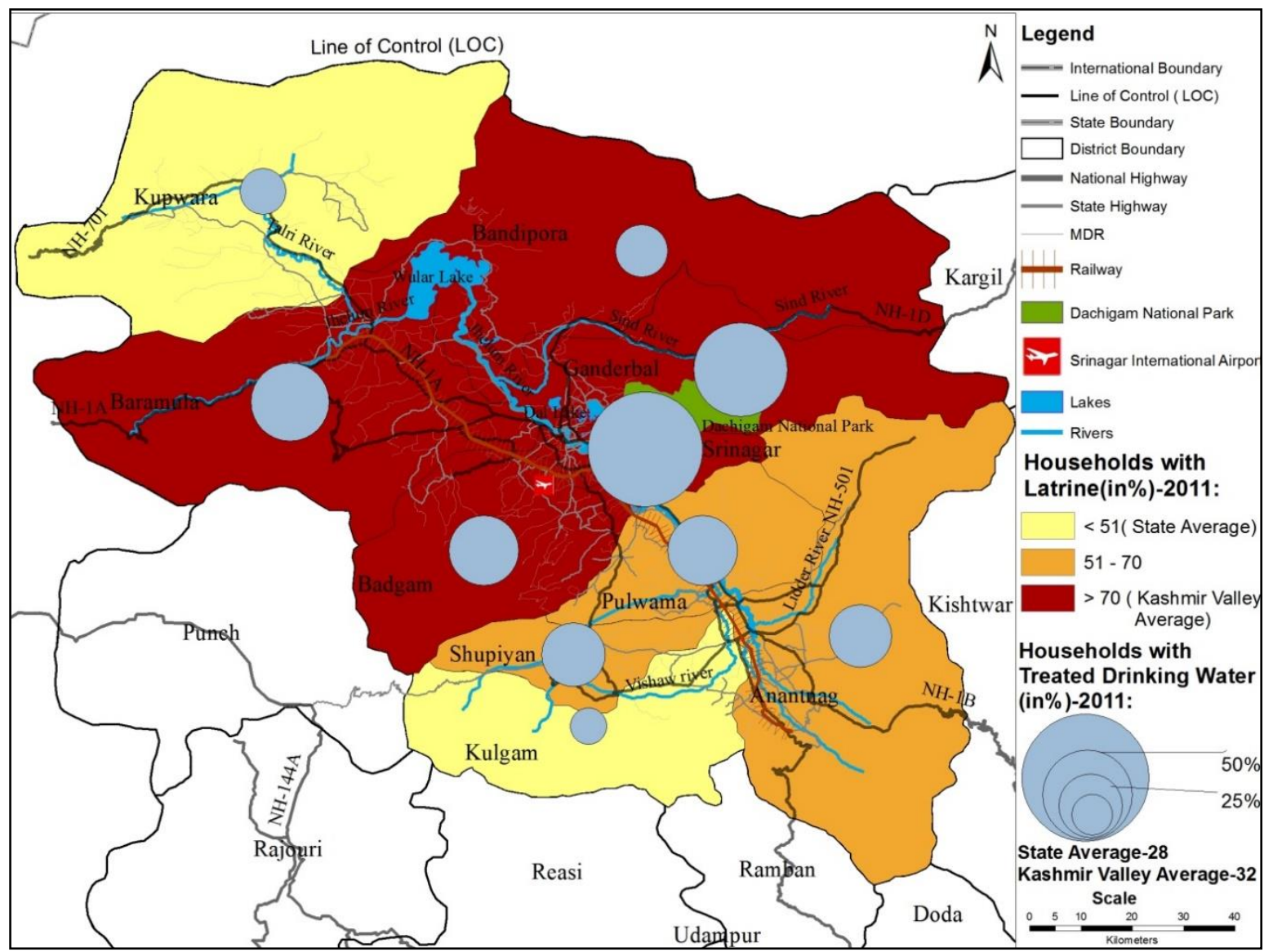

Source: Census of India, Primary Census Abstract, 2011

Household's amenities are determined by the availability of drinking water, latrine facilities and its sanitation level. Percentage share of households with latrine are lower than the state average (51\%) and Kashmir valley average $(70 \%)$ in Kulgam and Kupwara districts. Percentage share of households with treated drinking water is higher than the state $(28 \%)$ and Kashmir valley average (32\%) in the Srinagar, Ganderbal and Baramula districts. On the other hand, there are fewer percentage shares of households with treated drinking water in Kupwara, Kulgam and Bandipora districts. It can be concluded that there has not been given attention in terms of drinking water and toilets facilities in the districts of Kupwara, Kulgam and Bandipora by policy makers and social scientists of the Jammu and Kashmir state. 


\section{Map 4: Percentage Share of Households with Electricity and Percentage Share of Households with using Firewood (2011)}

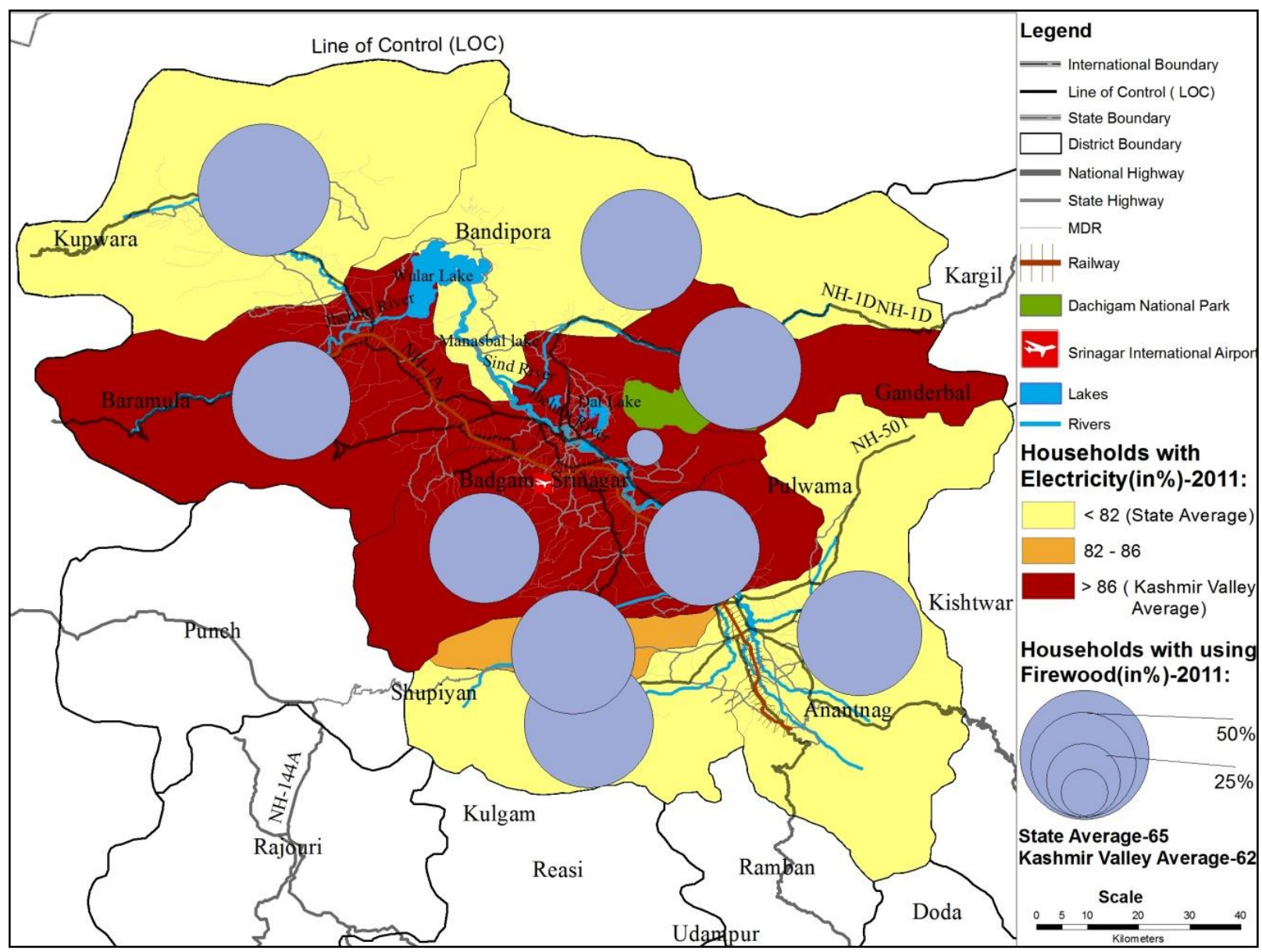

Source: Census of India, Primary Census Abstract, 2011

Energy assets have a significant role in the development of tourism, business and small-scale industry and information technology. Though, Kashmir valley has been a potential power generation of electricity. Percentage share of households with electricity is lower than the state (82\%) and Kashmir valley average $(86 \%)$ in Kupwara, Bandipora, Kulgam and Anantnag districts. Whereas electricity supply is higher in the Srinagar, Baramula, Badgam, Pulwama and Ganderbal districts. Households which are using firewood on a daily basis are high in number in the districts of Kulgam, Kupwara, Bandipora and Anantnag. The reason is that these are near to forests and far from the urban areas. The households using firewood are lower than the state $(65 \%)$ and Kashmir valley average (62\%) in Srinagar, Badgam and Pulwama districts. These districts are widely used electricity as main source of energy consumption. 


\section{Map 5: Percentage Share of Households with using LPG/NPG (2011)}

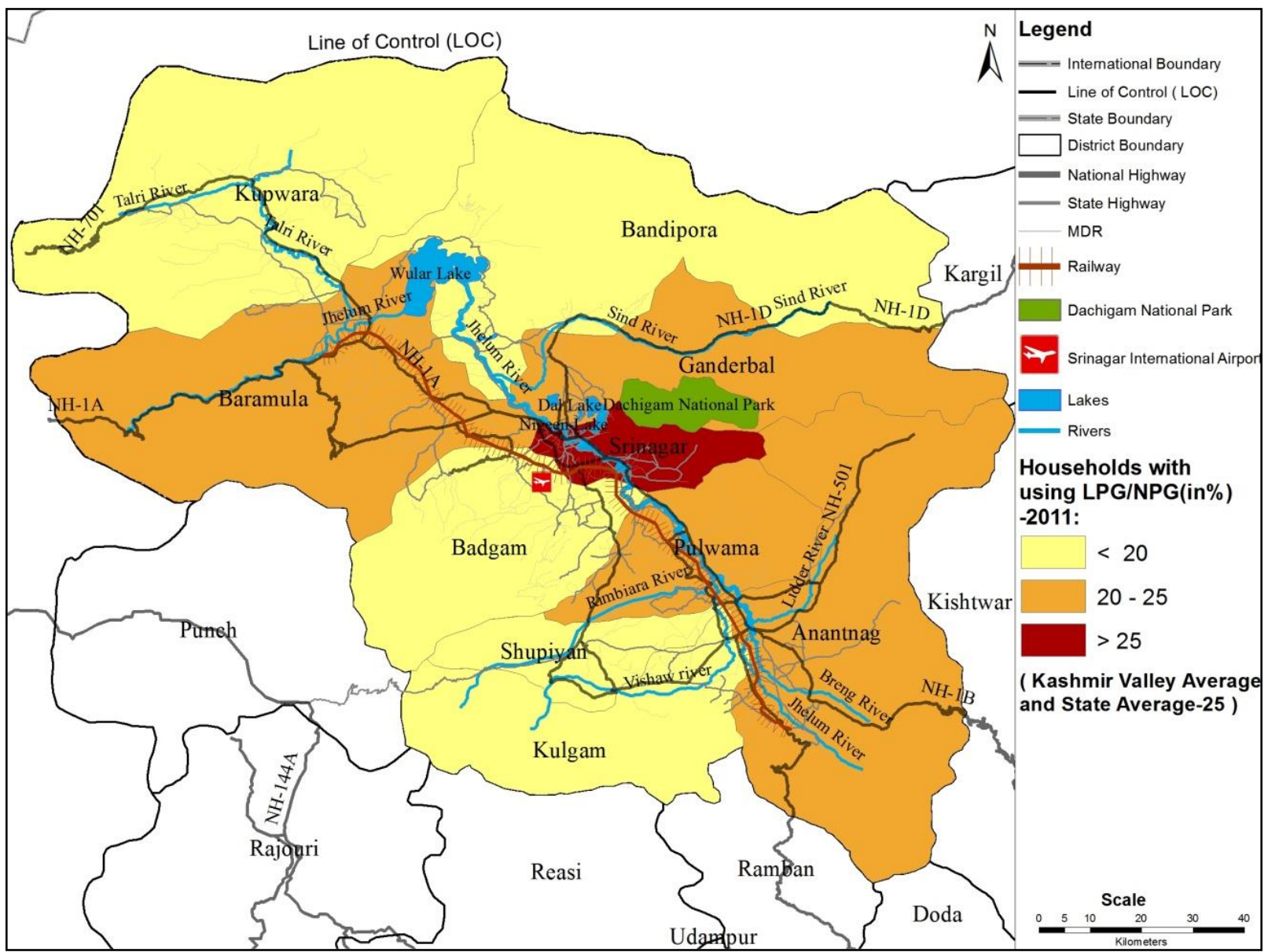

Source: Census of India, Primary Census Abstract, 2011

LPG/NPG is also a major source of energy. It is predominantly utilized by the urban dwellers compared to the rural dwellers. Percentage share of households using LPG/NPG is higher than the state and Kashmir valley average (25\%) in Srinagar district. While there is lesser usage of LPG/NPG in other districts of Kashmir valley. People are used firewood as main fuel for cooking purpose particularly in forested region on a daily basis. 
Map 6: Percentage Share of Occupied Census Houses used as Shops/ Offices and Percentage Share of Occupied Census Houses used as Hotel/Lodge/Guest House etc. (2011)

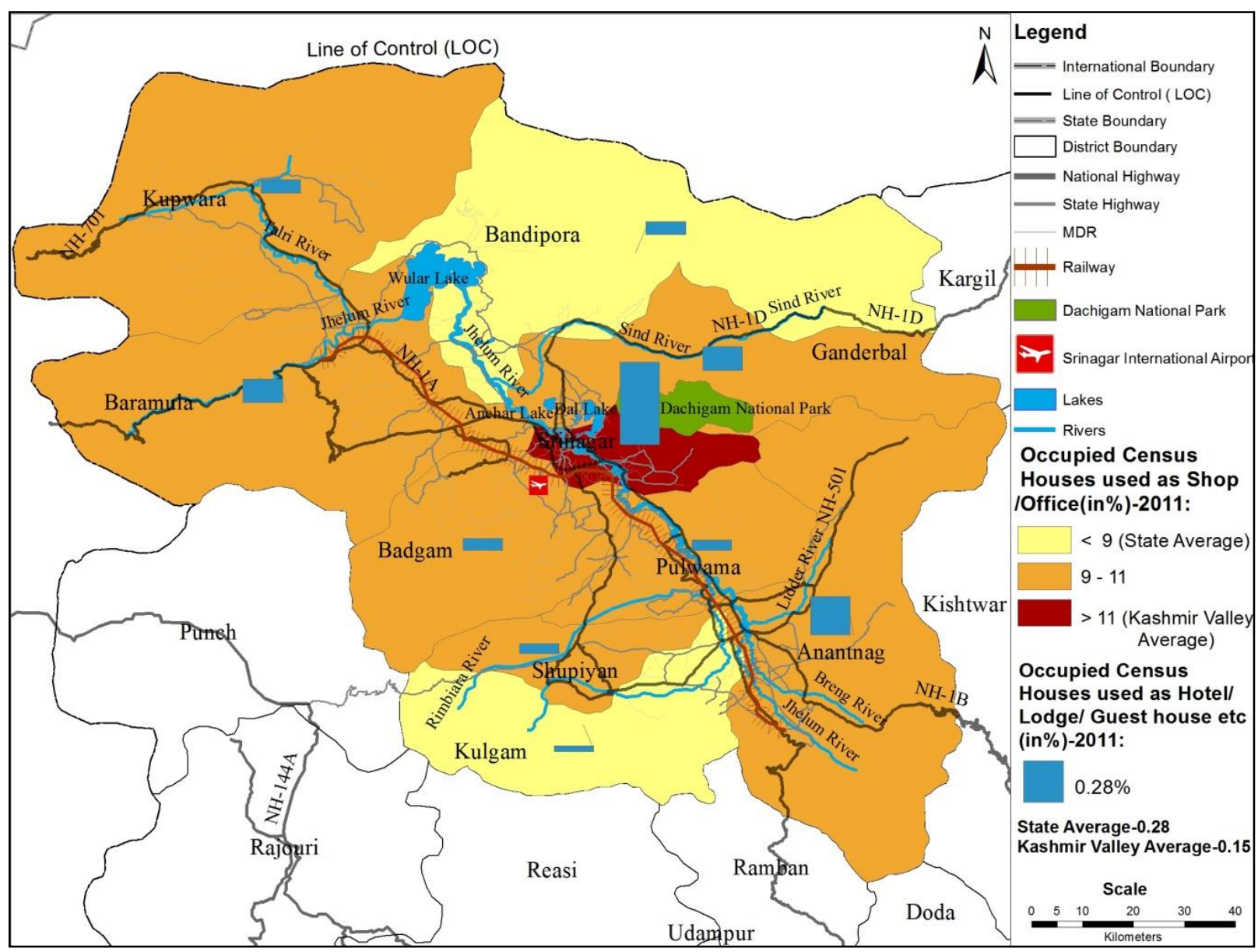

Source: Census of India, Primary Census Abstract, 2011

The commercial assets such as shops, hotels, offices and lodge etc. are predominantly located in the urban centers of the Kashmir valley. Percentage share of occupied census houses which are used as shops/offices are higher than the state average (9\%) and Kashmir valley average (11\%) in Srinagar district. Whereas these are lower than the state and Kashmir valley average in Bandipora and Kulgam districts. Percentage share of occupied census houses which are used as hotel/lodge/guest house etc. are higher than the state $(0.15 \%)$ and Kashmir valley average $(0.28 \%)$ in Srinagar, Anantnag, Baramulla and Ganderbal districts. Tourism is the main cause for concentration of commercial assets in these districts. 


\section{Map 7: Percentage Share of Households with availability of Mobile Phones and Computer/Laptop (2011)}

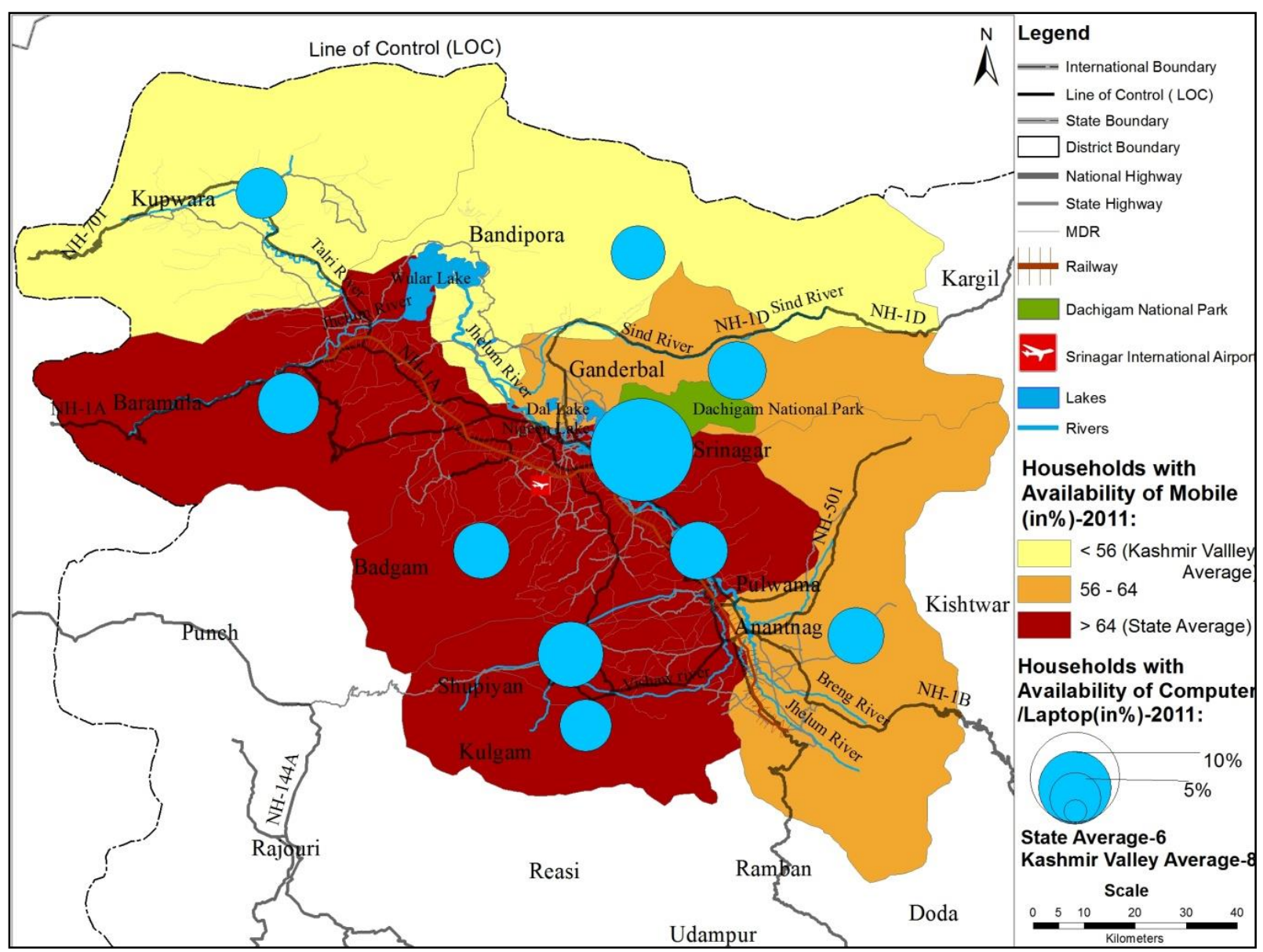

Source: Census of India, Primary Census Abstract, 2011

Percentage share of households with availability of mobile phones is lower than the Kashmir valley average $(56 \%)$ and state average $(64 \%)$ in Bandipora and Kupwara districts. While percentage share of households with availability of mobile phones is higher than the state average and Kashmir valley average in Srinagar, Badgam, Shupiyan, Kulgam, Baramula and Pulwama districts. Percentage share of households with availability of computer/Laptop are higher than the state average $(6 \%)$ and Kashmir valley average $(8 \%)$ in Srinagar district. The reason is that it is the educational, administrative, commercial and tourism hub of the Kashmir valley. 


\section{Map 8: Post offices per 100 sq. km (2011-12) and Percentage Share of Households with availability of Television (2011)}

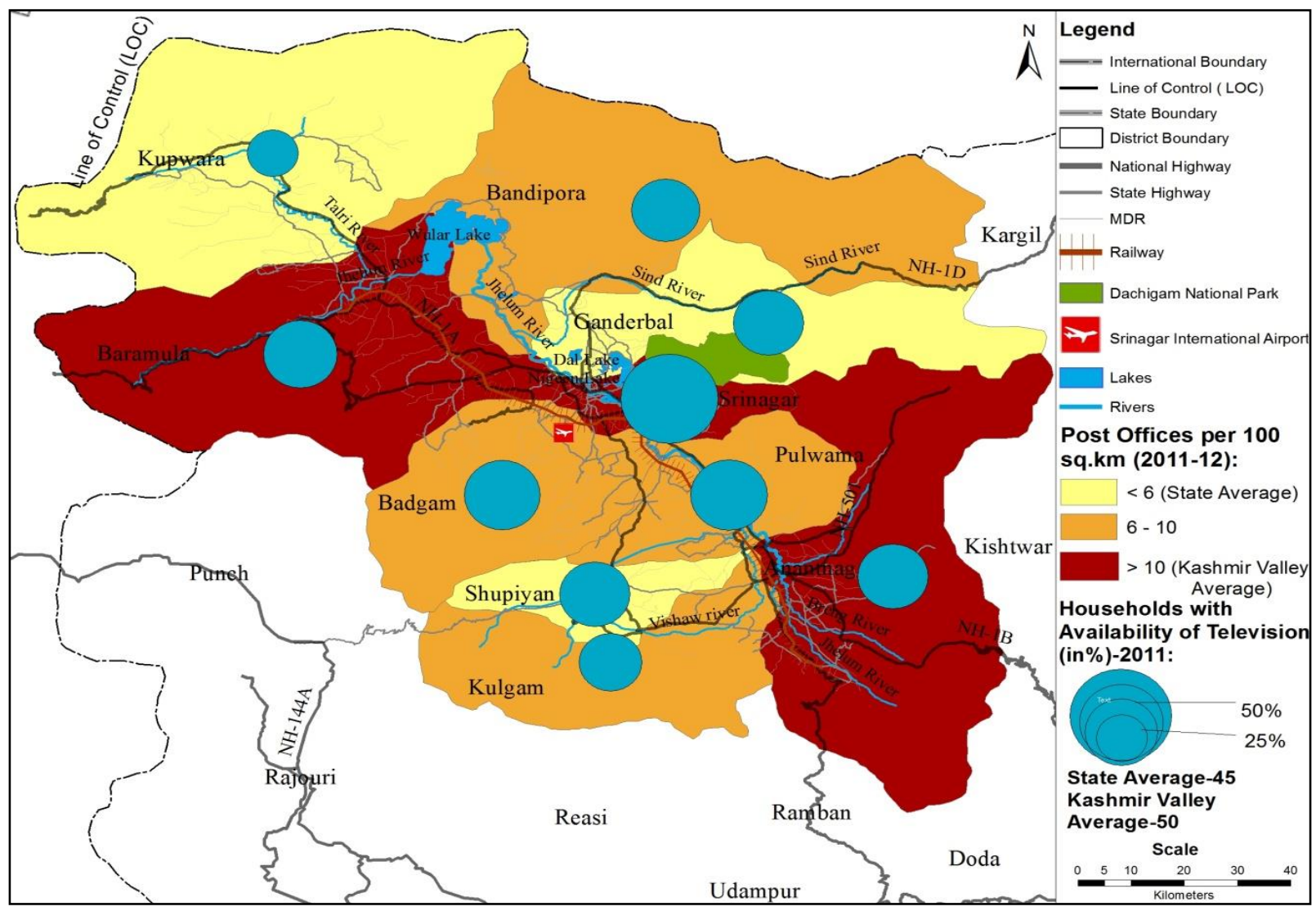

Source: Directorate of Economic and Statistical Department (DESD), Jammu \& Kashmir, 2011-12 and Census of India, Primary Census Abstract, 2011

Postal network and television are an integral and significant part of communication technology. Posts offices per 100 sq. km is higher than the state average (6) and Kashmir valley average (10) in the Srinagar, Baramula and Anantnag districts. As these are highly urbanized districts of Kashmir valley. On the other hand, Kupwara, Bhuiyan and Ganderbal districts are below the state and Kashmir valley average. Percentage share of households with availability of television is higher than the state average (45\%) and Kashmir valley average (50\%) in Srinagar, Baramula and Pulwama districts. Whereas percentage share of households with availability of television is lower than the state average and Kashmir valley average in Kupwara, Kulgam and Bandipora districts. 


\section{International Journal of Social science and Economic Research}

ISSN: $2455-8834$

Volume: 05, Issue: 06 "June 2020"

\section{CONCLUSION}

The Kashmir Valley has great potential for development because its natural resources. The results depict that there are shortages of hospitals, schools, colleges, dispensaries, electricity, toilets and drinking water facilities in the Kupwara, Ganderbal, Bandipora and Kulgam districts. The post offices, road connectivity, availability of mobile phones, television etc are also poor in these four districts compared to other remaining districts of the Kashmir valley. The social amenities and services are not up to the standard norm of urban and regional planning in these districts. The locational disadvantage, inadequate infrastructure and poor governance are prominent reasons for the lack of proper social infrastructure. There should be precise governance system in the insurgent and least developed districts areas in order to establish peace and tranquillity. There cannot be done any kind of social, economic and cultural development without having peace in this region. There is needed to make districts and regional planning strategies in order to address the issues of development in the Kashmir valley. Developmental strategies is supposed to be formulated and implemented inclusively and sustainably considering all people and stakeholders participation.

\section{REFERENCES}

1. Aderamo, A. J., \& Aina, O. (2011). Spatial inequalities in accessibility to social amenities in developing countries: A case from Nigeria. Australian Journal of Basic and Applied Sciences, 5(6), 316-322.

2. Bagchi, S., \& Chattopadhyay, S. (2004). Decentralised urban governance in India: implications for financing of urban infrastructure. Economic and Political Weekly, 39(49), 5253-5260. Retrieved from https://www.jstor.org/stable/4415872

3. Bhagat, R. B. (2011). Urbanisation and access to basic amenities in India. Urban India, $31(1), 1-13$.

4. Census of India. (2011). Primary Census Abstract. India: Office of the Registrar General \& Census Commissioner, Ministry of Home Affairs, Government of India.

5. Diamond, D. B., \& Tolley, G. S. (1982). The economics of urban amenities. New York, United States of America: Academic Press.

6. Digest of Statistics. (2013-14). Retrieved from Directorate of Economics and Statistics, Government of Jammu and Kashmir: http://ecostatjk.nic.in/publications/publications.htm

7. Haque, I. (2016). Infrastructure development and access to basic amenities in Class-I cities of West Bengal, India:Insights from census data. Journal of Infrastructure Development, 8(1), 36-84. doi: 10.1177/0974930616640089 
8. Haque, S., \& Wani, N. A. (2013, October). An evaluative study of ICDS in Kashmir. International Journal of Scientific and Research Publications, 3(10), 01-05.

9. Kumar, A. (2015). Indian urban households' access to basic amenities: Deprivations, disparities and determinants. Margin-The Journal of Applied Economic Research, 9(3), 278-305. doi:10.1177/0973801015579754

10. Kundu, A., Bagchi, S., \& Kundu, D. (1999). Regional distribution of Infrastructure and basic amenities in urban India: Issues concerning empowerment of local bodies. Economic and Political Weekly, 34(28), 1893-1906. Retrieved from http://www.jstor.com/stable/4408183

11. Mohiuddin, S., \& Hashia, H. (2012, September). Regional socio-economic disparities in the Kashmir Valley (India) - a geographical approach. Bulletin of Geography. Socioeconomic Series, 18(18), 85-98. doi:http://dx.doi.org/10.2478/v10089-012-0021-5

12. Planning Commission. (2003). State Development Report. Jammu and Kashmir. New Delhi: Government of India. Retrieved from http://14.139.60.153/handle/123456789/5331

13. United Nations General Assembly. (2013). A life of dignity for all: accelerating progress towards the millennium development goals and advancing the United Nations development agenda beyond 2015. A Report of the Secretary-General. New York: United Nations. 